\title{
"Why am I changed?" \\ The convergent process in a multilingual community: Speech Accommodation Perspective
}

\author{
Nanin Verina Widya Putri ${ }^{\mathrm{a},{ }^{,},}$, Slamet Setiawan ${ }^{\mathrm{b}}$ \\ ${ }^{\mathrm{a}, \mathrm{b}}$ Universitas Negeri Surabaya, Indonesia \\ *Corresponding author. E-mail address: naninputri@mhs.unesa.ac.id
}

\begin{abstract}
This study aims to investigate how the students' university accommodates their local/regional language to the new language that they stay temporary for their study program at university. Two students were involved in this study from different regions in East Java which took four years of study in UNESA. They have different dialects from their regions and should adjust new dialects in Surabaya for their new environment. For this reason, this study is intended to know how students-university accommodates their home-language to Surabaya language as the place that they study at university. To do so, the data was gained in depth-interviews with structured interview techniques. Further, the analysis revealed that the university students changed their linguistic features because many reasons; they wanted to be approved in their community, they wanted to create meaningful or communicative communication with interlocutors, and they would get the same perceptions with their interlocutor. This research is beneficial for researchers who interest in the area of speech accommodation, especially in the Indonesian context since it is rarely conducted in Indonesia. Moreover, from the results of this study, it is to be more useful when the future study involved more students from different regions and different regional languages that can show many varieties of evidence for the speech accommodation process in a multilingual society.
\end{abstract}

Keywords: sociolinguistic, multilingual community, speech accommodation

\section{INTRODUCTION}

In society, it can be founded many people from a different region, gender, status, age, level of education, country, etc. As Wardaugh (2006) said, society is a group of people with having certain purposes. They meet for some purposes for the need of life. For example, in reality, we can find a certain group of people from another place just come to our city for their business. Interestingly, sometimes the language that they used is also different from our language. How people use language in the different area become an interesting study of researchers (e.g. Wardaugh, 2006 and Holmes, 2013). They are concerned about how language use and how language expresses their identity which relates to one to another group. Specifically, they focus on the study of sociolinguistics.

Multilingualism occurs when someone moves to another place, meet new people from different area and live in a new place which has a different language with them. Consequently, they speak a new language which uses by the dominant community (Bell, 2006). They speak more than one or two languages in a new place. Aronin (2019) said that multilingualism refers to the study of how people use more than one-two languages which presence of the number of 
languages in a country, city, or community. In other words, within multilingualism, there are multilingual people or communities in a certain domain of society.

In the university context, the multilingual community is presented in their environment. They show many language varieties among them. The language variety that emerges in students' university is their regional language. Some of the students who study in university bring their home-language (regional language) which is different from the language in the area of the university used. Linguistic diversity could appear in students' communities which tackled the issue of a speech community (Jacquemet, 2018). Consequently, they have to adjust to the language that society often used in the university.

The university environment also displays how the speech community exists. A speech community is defined as a group of people who shared the same language. A family is one of the examples of a small speech community. They have the same language to share. Bloomfield (1933) followed by Wardaugh (2006) defined speech community as "a group of people who use the same set of speech signals". Then, as Gumperz (1972) cited in Jacquement (2018), said that the speech community is "any human aggregate characterized that is regularly or frequently used by a group of people". However, when they move to another place, they will meet different speech communities. It is because they have a different language that they usually used.

Further, some of the students in university come from a different area, they have their speech community. It could be referred to as their dialects. For example, in the Javanese language, the dialects that the speakers used are different from their regional. Students from Bojonegoro (one region in Java) has different dialect with the students from Banyuwangi (one region in Java). Their language could differ in terms of grammar, pronunciation, and vocabulary. Therefore, when they move to a new place or new region for their study, they will possess a new language that the new place used. It has a connection with Nilsson's (2015) study, it was about dialect accommodation. He examined how Swedish adolescents changed their dialect situation in the area studied. The result showed that they changed their dialect to their interlocutors to maintain interpersonal relationships.

From the problem that appears in the university above, it can be said that most students university from different regions brought their regional language to the university environment will affect how they communicate. In which the dominant language will be the language that the students used in a multilingual environment (Aronin, 2019). They have to accommodate their language to the convergence language of the community. It means that the multilingual community integrated with the speech accommodation where they have to adjust the language that the convergent people exist.

Speech accommodation always occurs when someone wants to be approved in a new environment. There are many previous studies about speech accommodation, those are focused on the sociolinguistic issue gender-related in children's speech accommodation (Robertson \& Murachver, 2003), issue on how adults accommodate their conversation in partnership (Thomson, Murachver, \& Green, 2001), and how men and women consider their language choice (Al-Harahsheh, 2014). However, few studies in the Indonesian context, focus on how students' university accommodate their language with the language that the convergent community has when they study in university. Therefore, the researcher motivated to conduct research based on three research questions below: What changes do the university students undergo in their linguistic features? Why do they change their linguistic features? What consequences do the speakers get from the changes? 


\section{LITERATURE REVIEW}

\section{SOCIOLINGUISTICS AND ITS DEFINITION}

Language and society cannot be separated from each other. They are correlated in many factors, included social structure factors (Wardaugh, 2006). When society exists, they use language for their communication. Moreover, the relationship between language and society can be studied in sociolinguistics (Holmes, 2013). The way people use language, how they negotiate in society, how they express their language and all about language and society refer to the study of sociolinguistics. For this reason, sociolinguistics is important to be learned to understand society's demands and purposes.

Sociolinguistics theory refers to all discussions about language and society. According to Holmes (2013), sociolinguistics serves the information of the way people act using language, how language works, how social relations influence the community, and how language shows their social identity. In 1971, Gumperz asserted that sociolinguistics is the study to attempt the correlation between social structure and linguistics structure which also observed how they changed. It means that sociolinguistics has a role in the development of linguistic evolution.

In 2002, Chambers gave more details that sociolinguistics learns how language is used in society, and he said that sociolinguistics is the most productive study in the four decades for social evaluation of linguistics variants. The explanation above proved that sociolinguistic still become an interesting area to be observed. Therefore, many researchers encourage to find the relationship between language and society, such as Wardaugh (2006) and Holmes (2013). From the previous studies above, it can be concluded that sociolinguistics study has a pivotal role in understanding the purposes of society or community. One of the sociolinguistics concerns is a multilingual community where occurs in any area of life. The explanation below deals with the multilingual community.

\section{MULTILINGUAL COMMUNITY CREATES MULTILINGUAL PEOPLE}

A multilingual community happens where many groups of people come from different regions or areas that bring their language or a different variety of languages. It refers to dialect, accent, etc. In fact, the multilingual community has many sources showing different people. When they meet a certain purpose in life, they create a new environment that usually involved changes in their language. Moreover, multilingual speakers mean they are able to speak more than one language. They have maintained one language for their first language (L1). Then it can also occur when the speakers move to another place and acquired another language so that they could be called bilinguals.

Moreover, when people meet for trade or another purpose, they have a different language and linguistics diversity, then, a multilingual community occurs at that time. Consequently, they have to negotiate to meet their needs, they express their general words to make the interlocutor understand, and they tend to show their common linguistic feature to assist the understanding of their interlocutor. Babatunde (2014) revealed that the multilingual community developed the social-cultural and economic contact between people who lived across the frontiers of Nigeria and Benin. It proved that the multilingual community has many benefits for speakers.

In the process of negotiation, the speakers tend to adjust their language to their interlocutors. For this reason, when this condition takes place for a long duration, the speakers 
will acquire the language that they usually interact with the interlocutor. It is because they were exposed to the language. Furthermore, the speakers will become multilingual when they have many potential, such as; they have a strong interest in the language that they haven't learn before, they have a certain purpose to acquire the language (e.g. for business, entertainment, study program, information gathering, etc.), they are immigrants people, language immersion children, they have a community who has strong demanded to acquire the language (Babatunde, 2014).

For this reason, the multilingual community can create multilingual people who acquire more than two languages because of their interaction. Nowadays, the situation of the multilingual community often happens in many places, for instance in the market, in the area of immigrants, and also in the university environment. Since they come from different countries or cities or communities, they have high linguistic diversity in their new place. For this reason, they have to adjust what language they need for negotiation. This mechanism refers to the theory of Speech Accommodation. It will discuss the next explanation.

\section{SPEECH ACCOMMODATION THEORY}

The theory of speech accommodation proposed by Howard Giles in the 1970s. He defined speech accommodation as the adjustment of someone's speech to linguistics characteristics of someone he interacts with. By his theory, he explained how speakers accommodate their language in conversation. Moreover, Speech Accommodation Theory (SAT) has broadened in the 1980s. It has two key concepts, those are convergence and divergence (Bell, 2006). Those concepts are two linguistics strategies that speakers applied in their interaction. Convergence refers to speakers' effort to show their same style of speech with their interlocutors. Meanwhile, the divergence refers to the speakers' reaction against the interlocutor because of their differences (Bell, 2006).

From the explanation above, it can be seen in a reality that a multilingual community shows the condition of convergence and divergence. However, the aspect of convergence is the most extensively researched speech accommodation (Sachdev \& Giles, 2004). The speakers will change their linguistic features (e.g. pronunciation, grammar, spacing, etc) because they tend to converge in their community or interlocutor (Holmes, 2013). The more speakers have similarities with their interlocutors it will gain the reward of their conversation.

One of the rewards of conversation is approval in their community. Moreover, Bell (2006) asserted that speakers who change their linguistic features are an account of their social approval. It is because when speakers are approved in the multilingual community, they gain effective communication among them. Then, the greater desire of the speakers for gaining approval, the greater communication would be the convergence (Bell, 2006). In other words, the convergence tends to create a friendly intergroup and give a positive evaluation of recipients.

In Indonesia University, some of the students come from different regions. They bring their regional language. Consequently, the multilingual community occurs among them. This means the language that they have will be influenced by the new language in the multilingual community. As SAT declared that speakers will converge their language when they meet the multilingual community, the speech accommodation occurs at that time. For this reason, this present study will examine what linguistic features changed by students' university undergo, why they changed it, and what the consequence of their action. 


\section{METHOD}

This research used qualitative research and applied case study methodology. The data gained by using interviews. The interviews consist of 3 parts of questions (See Appendix A). The first part focuses on the linguistic features that the student changed (research question number 1). The second part focuses on the reasons students change their linguistic features (research question number 2). The third part focuses on the consequences the students get from the changes (research question number 3). The students were university students who have stayed for 4 years in Surabaya to study the English language. They are from a different region in East Java who different dialects from Surabaya. The first student is from Bojonegoro regional who bring the Bojonegoro dialect, and the second student is from Banyuwangi who brings the Banyuwangi dialect but not the origin of the Banyuwangi language.

After the researcher interviewed the two students by telephone. The researcher gained the data. Moreover, the researcher analyzed the data used steps by Creswell (2014). Those are organizing and preparing the data for analysis, coding and reducing, interpreting, and representing. In other words, the first step transcript the interview and selected the important information. Then, the researcher understood the data by organizing it, the researcher continued the next step. The researcher interpreted the data by describing the result of codes by each category. After the researcher got the final result, the results of the finding were represented in the form of paragraphs.

\section{FINDINGS AND DISCUSSION}

In this section, the researcher presents the results of this study. The results consist of three sections. The first section about what kind of linguistic features are changed from the students. The second section about the reason the students change their linguistic features. Then, the third section about the consequences of changing the linguistic features. Where all the sections are for answering the research questions of this study.

\section{THE LINGUISTIC FEATURES THAT THE STUDENTS CHANGE}

From the interview that the researcher has conducted, the first section of the question focuses on what linguistic features that the students change from their home-language to the language that they stay in the multilingual community since they are from a different region in Java. In other words, this part aims to answer research question number one. The first student is from the Bojonegoro region, and the second student is from the Banyuwangi region which has a different language from Surabaya.

They declared that some linguistic features differ from their home language. The linguistic feature refers to the vocabulary and the dialect of Surabaya native speakers. The linguistic features that students told in an interview that differ from their home-language and language they used when stayed in Surabaya are shown below. 
Table. 1 The changes of linguistic features (Student 1)

\begin{tabular}{|c|c|c|c|}
\hline Home Language & Surabaya Language & $\begin{array}{l}\text { The language } \\
\text { that they used } \\
\text { while } \\
\text { Surabaya } \\
\end{array}$ & $\begin{array}{l}\text { English } \\
\text { translation }\end{array}$ \\
\hline piee to & Yo opo sih rek? & Yo opo sih rek? & How can it be? \\
\hline Sampean iku & Kon iku & Kon iku & You are. \\
\hline Lho seng tenan to? & Iyo a? & Iyo a? & Really? \\
\hline becek & buwuh & buwuh & $\begin{array}{l}\text { come to the } \\
\text { wedding } \\
\text { invitation }\end{array}$ \\
\hline
\end{tabular}

Table 2. The Changes of Linguistic Features (Student 2)

\begin{tabular}{|c|c|c|c|}
\hline $\begin{array}{l}\text { Home } \\
\text { Language }\end{array}$ & $\begin{array}{l}\text { Surabaya } \\
\text { Language }\end{array}$ & $\begin{array}{l}\text { Language that they used in } \\
\text { Surabaya }\end{array}$ & English translation \\
\hline Pie iki? & Ya opo? & Yo opo? & How can it be? \\
\hline $\begin{array}{l}\text { bocah- } \\
\text { bocah }\end{array}$ & arek-arek & arek-arek & children \\
\hline kanggo & gae & gae & It is for... \\
\hline sesuk & mene & mene & tomorrow \\
\hline
\end{tabular}

As showed in Table 1 and Table 2, after staying in Surabaya for about 4 years, they asserted that they changed their language dialect, included the linguistic features that become the Surabaya dialect. For instance, it shows in Table 1, student 1 changed her home-language "sampean iku" becomes "kon iku". In Table 2, student 2 changed her home-language "sesuk" becomes "mene".

Although they changed their language to the Surabaya dialect, when they come to their hometown they tried to change their language to their home-language, but sometimes they still express the Surabaya dialect naturally. The data above are proved by the statement of the students when they were interviewed.

Researcher: The first question, after you stayed in Surabaya for about 4 years, what linguistic features (vocabulary) that you get from Surabaya? Is there any difference from Banyuwangi?

Students 1: Hm, yes, there is.

Then, she also said.

Student 1: Yah, but when I go back to Banyuwangi sometimes I still used Surabaya vocabulary and dialect, but when I am in Banyuwangi, I have many friends there, they felt like I am absurd to use that language, it is because I used Surabaya dialect and vocabularies. At that time, I directly remember that I am in Banyuwangi I have to change my dialect and language, although I realize sometimes I still used the Surabaya language naturally. 
Student 2: Yes, there are changes but I think it is not significant.

However, student 2 also said that there is vocabulary that has similarity because they have the same province in Java. That is showed below.

Table 3. The students' vocabulary

\begin{tabular}{|c|c|c|c|}
\hline \multirow{2}{*}{ Students 2 } & $\begin{array}{c}\text { Home- } \\
\text { Language }\end{array}$ & $\begin{array}{c}\text { Surabaya } \\
\text { Language }\end{array}$ & English \\
\cline { 2 - 4 } & dolan & dulin & play \\
\hline
\end{tabular}

From the results above, it can be concluded that not all linguistic features of students changed to their new environment in the multilingual community. It is just some of their linguistic features changed because they stay for about 4 years in the multilingual community with the dominant people of Surabaya. However, when they come back to their hometown they usually still used the Surabaya dialect naturally even they don't mean to change it.

\section{THE REASONS THE STUDENT CHANGE THE LINGUISTICS FEATURES}

In this section, the researcher portrayed the results of the interview related to the reasons the students changed their linguistic features. The students told that they changed their linguistic features from their home-language to the Surabaya language will explain below.

For student 1, she asserted that she won't change their language but she felt the changes in her language naturally. She told that the changes occurred when she was in a situation where the dominant people used the same language so that she accommodated her language to them. It is proved by her statement in the interview as shown below.

Student 1: Yes, hmm. Honestly, I didn't mean to change my language but it seems like it appears immediately without my awareness, so that when I stayed in Surabaya and my friends always used the Surabaya dialect, automatically it triggers me to speak like them.

Moreover, she said that the reasons why she changed her language because two reasons; with whom she interacted and where the interaction takes place. She told as below:

Student 1: Yes, there is. I change my language depend on what people I interact with and where I stand at that time.

Then, for student 2, she told that the changes in her language because she wanted to adjust her friends' language or the Surabaya native speaker to spread her relationship in Surabaya. In other words, she wanted to be approved in her new environment. Moreover, she revealed that she changed her language depend on the people with whom she interacts with. Her statements are below.

Student 2: In my opinion, my reason change my language is to adapt to my environment, if I can adjust their language, it means I will be helped to be part of them in interaction. Then, it 
also gives me chance to spread my relationship. So that I felt like they felt comfortable when I speak with their language.

Student 2: I change my language depending on who is people I interact with.

From the results above, the students told that they changed their linguistic features from their home language to the Surabaya language because they wanted to be approved by their community if they change or accommodate the language they presumed that they will get more meaningful communication with interlocutors. They also said that by changing their language there is no different perception of communication.

\section{THE CONSEQUENCES FOR CHANGING THE LINGUISTIC FEATURES}

In this section, the researcher will describe the result of the interview with the students related to the third research question. That is the consequence of changing linguistic features. Here, the students revealed their statements insides, positive consequences, and negative consequences for themselves.

\section{POSITIVE CONSEQUENCES}

Student 1 said that the positive consequence of changing their linguistic features she could be more comfortable, friendly, and creating effective communication in the Surabaya community. She felt she was accepted in her community because her friend did not isolate her. After all, she accommodated her language to the interlocutor. It shows in her statement below.

Student 1: When I am in Surabaya, the positive consequence that I get from using the Surabaya language is I felt like I close to them. It means that I seem like I am not from a certain region, yes, Ifelt more comfortable with them.

Student 1: Therefore, the positive consequence that I get is like there is no diversity among us, I felt I am not from a certain region. I use the Surabaya language so we use the same language when we communicate.

Moreover, Student 2 said the positive side for her, she could accept her friends in Surabaya. After she changed her language she spread her relationship among her multilingual community. She also asserted that it increased her knowledge as well about the Surabaya language. For this reason, she could speak the Surabaya dialect during doing her program study in Surabaya.

Student 2: Yes, maybe as I said before, the positive consequence that I get maybe I could be accepted in my multilingual community (Surabaya community) and it also helps me to expand my relationship. Moreover, when I changed my language it gives me knowledge of a new language, it seems like "Oh there is a new vocab that I get". But, the changes not significant. 


\section{NEGATIVE CONSEQUENCES}

In response to negative consequences, the students said that they have not much negative from changing their language. However, they asserted that sometimes when they meet someone from their hometown they are treated differently because they used the Surabaya dialect and they changed their linguistic features of home-language. It shows below.

Student 1: Sometimes, the changes immediately come, it seems like I didn't recognize it, but I said it when I am in my workplace. Then, my colleagues heard what I said they directly said "Oh ya, I trust you, you are Surabaya one right now," and they felt like I am different from them because they are not familiar with the word that I said. It seems like anything awkward with me when I used the Surabaya language when I go back to Banyuwangi.

Student 2: Perhaps, at first when I was in Surabaya I was rather shocked by the new words or vocab that my friends said. Therefore, I have to adjust and try to understand what people said, and I felt like "Oh yea, there is a new word that I get from here". So that I tried to adapt their language to avoid misunderstanding and we have different languages.

From the results of positive and negative consequences above, one of the benefits they accommodate their languages because they received more positive consequences, that are; they could be accepted by their community, they could build the better relationship among their community, and they could be more knowledgeable in knowing the other language. In negative consequences, when they come back to their hometown they have to try changing their language to become home-language although sometimes they said some words in Surabaya language. It is because when they do not change their language to home-language, the people around them will judge them like a stranger.

\section{DISCUSSION}

From the results above, there are three main findings based on the research questions of this study. For the first finding related to the linguistics features, the findings showed there are many linguistic features from students' home language that changed after moved to Surabaya for 4 years. It is because they met the multilingual community which other students from a different region of Java, they found many languages in Surabaya. However, they used the Surabaya language in some vocabularies because of the dominant people there. For instance, from "bocah-bocah" becomes "arek-arek", from "pie to" becomes "yo opo sih?" which all the linguistic features has the same meaning, those are "bocah-bocah" in English is "children" and "pie to" in English " How is it?".

Those results are in line with the previous study by Jacquemet (2018), that linguistic diversity could appear in students' communities which tackled the issue of a speech community. He also asserted that to create a communicative interaction the speaker should accommodate their language to their interlocutor. Consistent with the statement of Giles \& Rayan (1982) cited in Setiawan (2013) about speech accommodation, they asserted that the speakers will converge their language toward interlocutors in interactive interaction. It implies that when the students (students) moved to Surabaya, they will meet the speech community in the university. In which they will accommodate their language to the place that they stay for temporary, and it refers to Surabaya language. 
Moreover, the second finding showed that students changed their language for many reasons. However, at first, they said that they don't want to change their language, but they said it changed naturally. Those reasons are they wanted to be approved in their community, they wanted to create meaningful or communicative communication with interlocutors, and they would get the same perceptions with their interlocutors. Those results are supported by the previous study of speech accommodation theory.

SAT (speech accommodation theory) said that the speaker will accommodate their language to the interlocutor to make cooperative interaction. The second finding agreed with the SAT theory. Moreover, it is consistent with the previous study (Holmes, 2013) that people tend to alter their language to someone who is talking with them. It implies that to reach effective communication they adapt to each other.

Then, for the third finding, the students get more positive consequences rather than negative consequences. The positive consequence is they could be accepted by their community, they could build a better relationship among their community, and they could be more knowledgeable in knowing the other language. In other words, if students get a more positive attitude from the changes in their language, they lead the language revival among their community (Setiawan, 2013). These results inform that on one hand, the speakers get more advantages by accommodating their language. On the other hand, when they come back to their hometown and did not use their home-language, the people who heard their language will act strangely.

\section{CONCLUSION}

The results and the discussion above showed that the university students who have stayed for 4 years in Surabaya for their study have accommodated their language to the new environment, which is the Surabaya language. They changed because of many reasons, those are they wanted to be approved in their community, they wanted to create meaningful or communicative communication with interlocutors, and they would get the same perceptions with their interlocutors. Then, the students get more positive consequences rather than the negative side. Moreover, when they accommodated their language they get approval from their community.

This research is beneficial for researchers who interest in the area of speech accommodation, especially in the Indonesian context. However, it is to be more useful when the future study involved more students from different regions and regional languages that can show much evidence for the speech accommodation process in a multilingual society.

\section{REFERENCES}

Al-Harahsheh, A. M. A. (2014). Language and Gender Differences in Jordanian Spoken Arabic: A Sociolinguistics Perspectives. Finland: Academy Publisher.

Aronin, Larissa (2019). What is Multilingualism? In David Singleton and Larissa Aronin (eds.), Twelve Lectures in Multilingualism. (pp. 334). Bristol: Multilingual Matters. http://www.multilingual-matters.com/display.asp?isb=9781788922050

Aronin, L. (2016) Multicompetence and dominant language constellation. In V. Cook and Li Wei (eds) The Cambridge Handbook of Linguistic Multicompetence (pp. 142-163). Cambridge: Cambridge University Press. 
Babatunde, S. O. (2014). Multilingualism Across borders : Nigeria-Republic of Benin as Case Study. European Scientific Journal, 7881(August), 518-529.

Bell, A. (2006). Speech accommodation theory and audience design. In: Keith Brown (ed), Encyclopedia of Language and Linguistics, 648-651. 2nd ed. Oxford: Elsevier.

Bloomfield, L. (1933/1984). Language. Chicago: University Chicago Press.

Chambers, J.K., Trudgill, P., Schilling-Estes, N. (Eds.), 2002. The Handbook of Language Variation and Change. Blackwell, Malden. Clark.

Creswell, J. W. (2014). Research Design: Qualitative, Quantitative and Mixed Methods Approaches (4th ed.). Thousand Oaks, CA: Sage. https://doi.org/10.1007/s13398-014$\underline{0173-7.2}$

Giles, H. \& Rayan, E. (1982). Prolegomena for Developing a Social Psychological Theory of Language Attitudes. Attitudes Towards Language Variation. E. Rayan and H. Giles (eds.). London: Edward Arnold.

Gumperz, J. J. (1971). Language in Social Groups. Stanford, CA: Stanford University Press.

Holmes, J. (2013). An Introduction to Sociolinguistics (4th). New York: Routledge. https://doi.org/10.1017/CBO9781107415324.004

Jacquemet, M. (2019). Beyond the speech community: On belonging to a multilingual, diasporic, and digital social network. Language and Communication, 68, 46-56. https://doi.org/10.1016/j.langcom.2018.10.010

Nilsson, J. (2015). Dialect accommodation in interaction: Explaining dialect change and stability. Language \& Communication, 41, 6-16. doi:10.1016/j.langcom.2014.10.008

Robertson, K. \& Murachver, T. (2003). 'Children's speech accommodation to gendered language styles. Journal of Language and Social Psychology, 22, 321-333.

Setiawan, S. (2013). Children's Language in a Bilingual Community in East Java. Saarbrucken: Scholar's Press.

Thomson, R., Murachver, T., \& Green, J. (2001). Where is the gender in gendered language? Psychological Science, 12, 71-75.

Wardaugh, R. (2006). ( $\left.5^{\text {th }} \mathrm{ed}\right)$. An Introduction to Sociolinguistics. USA: Wiley-Blackwell. 


\section{APPENDIX A}

\section{INTERVIEW SHEET}

\section{Participant's name :}

Date :

\section{Phone number :}

\section{Region:}

Questions :
What linguistics feature that is changed
(Research Question number 1)
The reason the speakers change the linguistic features (Research Question number 2)
The consequences the speakers get from the changes (Research Question number 3)
1. After you stay in Surabaya for 4 years to study, are there any changes in your linguistics feature between your regional language with Surabaya language? explain
2. What do the linguistic features you change? explain
3. Are there any grammatical structure changes in your language? explain
1. Why do you change your linguistic feature? explain
2. What condition or situation do you change your linguistic feature or your language? explain
1. After you changed your language features, what are the positive impacts that you get from? Explain...
2. Then, what is the negative effect of changing your language? explain.
3. What is your expectation from the changing of your language? explain. 